Wioletta A. Piegzik

Liceum Ogólnokształcqce nr VII we Wrocławiu

\title{
OD REFLEKSJI DO KONSTRUOWANIA WIEDZY I WSPÓLNOTY KOMUNIKACYJNEJ: WYNIKI BADANIA W DZIAŁANIU
}

\author{
From reflection to the construction of knowledge and communication \\ community: The results of action research
}

The purpose of the following paper is to consider the development of reflection in foreign language learners. Based on the results of action research, we show to what extent the performance of group tasks affected the perception of reality and influenced changes in the communication and learning behavior of participants of an action research project. Reflection is analyzed on the basis of statements contained in student diaries and transcriptions from video recording of discussions. This means that on the one hand, we are interested in the opinions, conclusions and evaluations made by learners, but on the other hand, we attach importance to the coherence between formulated judgments and practical group action. It is not uncommon that declarations are not in accordance with the activities undertaken and that, in consequence, their value is questionable. The paper also points to difficulties associated with becoming a reflective person as well as the restrictions connected with the scientific measurements of this process.

Keywords: reflection, constructivist perspective, task-based approach, action research, student's diaries

Słowa kluczowe: refleksja, perspektywa konstruktywistyczna, podejście zadaniowe, badanie w działaniu, dzienniczki uczestników badania

\section{Wprowadzenie}

Rozwijanie refleksji i związanej z nią postawy refleksyjnej u uczących się języka obcego stanowi dla glottodydaktyki zagadnienie tyleż ważne, co trudne i kło- 
potliwe. Ważne, ponieważ refleksyjny uczeń zastanawia się nad sobą jako osobą i uczniem oraz przebiegiem własnego uczenia się. Z reguły zna własne cele i potrafi obiektywnie oceniać własne działania. Samodzielnie organizuje sobie uczenie się, gdyż zdaje sobie sprawę, że od niego samego zależy przede wszystkim efekt końcowy. Jest najczęściej osobą świadomą i autonomiczną. Refleksja stanowi natomiast zagadnienie trudne i kłopotliwe, ponieważ stanowi ona proces wewnętrzny, jednostkowy i przez to subiektywny. Trudności pojawiają się więc przede wszystkim w obszarze metodologii, która ma pozwolić na rzetelne uchwycenie subiektywnego i indywidualnego procesu. Introspekcja nasuwająca się jako metoda badawcza, już nawet bez szczegółowej analizy, zdaje się być niewystarczająca lub przynajmniej wątpliwa. Dane uzyskane za jej pomocą mają charakter jednostkowy i dotyczą indywidualnego doświadczenia, skąd trudno o całościowe i niesubiektywne ujęcia, do jakich dąży nauka. Metody zaś zainspirowane behawioryzmem, kładące nacisk na obiektywizm i obserwację zachowań trącą niemocą poznania wewnętrznych procesów. Mogą one co najwyżej, „ostrzec nas przed możliwościq metodologicznych błędów (...) " (Cassirer 1998:36) lub redukować ludzką myśl do mniej złożonych i przez to bardziej uchwytnych wymiarów.

Jak zatem postąpić, aby jednostkowe i subiektywne dane zyskały miano wiedzy cechującej się ogólnością oraz obiektywizmem? W jaki sposób uchwycić i opisać refleksję, zachodzące u ucznia zmiany dotyczące jego sposobu myślenia i postawy związanej z podejmowanymi działaniami będącymi skutkami odbytej refleksji? W artykule proponujemy badanie $\mathrm{w}$ działaniu jako metodę badawczą nad refleksją. Należy ono do grupy badań jakościowych, które ukierunkowane jest zarówno na poznanie określonego zjawiska, jak i na wprowadzanie zmian w badanej grupie poprzez świadome zarządzanie zasobami ludzkimi (zob. Wilczyńska i Michońska -Stadnik 2010: 150). W ramach badania w działaniu możliwe jest także koncentrowanie się zarówno na aspektach teoretycznych, jaki i praktyce. Wiąże się to z możliwością dobrania różnorodnych narzędzi badawczych, które pozwalają na wieloaspektowe poznanie badanego zjawiska. W naszym wypadku chodzi o stymulowanie rozwoju refleksji uczących się poprzez pracę w grupie nad wspólnym zadaniem. Interesuje nas poznanie refleksji jako procesu mentalnego, który manifestuje się poprzez obserwowalne zachowania danej osoby, świadczące (lub nie świadczące) o odbytej refleksji. Wskazując na aspekt behawioralny nie mamy jednak na myśli 'czystego' podejścia ilościowego związanego np. z określoną liczbą powtarzanych zachowań danego typu, lecz ich jakość rozumianą w naszym wypadku jako np. otwartość na poglądy innych osób, wzajemną pomoc itp. Zakładamy, iż idąc właśnie tę drogą, tj. łącząc introspekcję i obserwowalne zachowania uczestników badania, zdołamy uzyskać w miarę możliwości wszechstronne i obiektywne spojrzenie na reflek- 
sję. Wychodzimy z założenia, że pominięcie introspekcji jako metody badawczej pomimo wspomnianych jej niedoskonałości jest niemożliwe, ponieważ „(...) bez bezpośredniego uświadamiania sobie uczuć, emocji, postrzegania, myśli nie potrafilibyśmy nawet określić zasięgu psychologii"(Cassirer 1998: 36). Natomiast brak odniesienia do obserwowalnych zachowań pozbawiłby nas pewności i obiektywizmu. $Z$ tego powodu refleksję uczących się analizować będziemy na podstawie ich wypowiedzi zapisanych w dzienniczkach uczestników badania (poziom werbalizacji myśli i emocji) oraz na podstawie transkrypcji nagrań wideofonicznych ukazujących konkretne zachowania uczniów podczas pracy nad projektem (poziom działania). Proponowana dwutorowość ma także na celu ukazanie różnorodności i złożoności natury ludzkiej refleksji w analizowanym obszarze nauczania/uczenia się języka obcego w grupie. Innym natomiast celem jest uzasadnienie wstępnej hipotezy mówiącej o tym, iż wartość refleksji wiąże się z jej skutkami, czyli zmianami, jakie powoduje u uczącego się. Można bowiem posiadać nawyk zastanawiania się nad różnymi elementami/zdarzeniami, ale nie wdrażać wniosków z refleksji do praktycznego działania. Wartość takiej refleksji jest z pewnością dużo mniejsza.

Mając na uwadze powyższe, w niniejszej pracy refleksja zostaje analizowana wraz z obserwowanymi działaniami komunikacyjnymi i działaniami związanymi z uczeniem się będącymi następstwem owej refleksji. Świadomi jesteśmy, iż można nam w tym miejscu zarzucić nadmierną troskę o pragmatyczność ludzkiego myślenia i działania. Na nasze usprawiedliwienie podajemy jedynie fakt, iż uważamy, że nauczanie/uczenie się języków powinno podążać (oczywiście nie w sposób ślepy i bezrefleksyjny) za wymaganiami współczesnego świata i kultury, które promują umiejętności praktyczne i skuteczność działania oraz komunikowania się, nie pomijając przy tym wartości współdziałania z innymi dla uzyskiwania wyższych wyników i satysfakcji płynącej z pracy w grupie.

W konsekwencji powyższego, pierwsza część pracy poświęcona będzie refleksji rozumianej jako proces mentalny, mający swe źródło w kontaktach społecznych, a także próbie ukazania grupy uczeniowej jako miejsca sprzyjającego jej rozwoju. W części drugiej opiszemy badanie własne oraz przedstawimy skutki odbytej przez uczniów refleksji. Zagadnienie rozwijania refleksji omówione zostanie w perspektywie zadaniowej, uwypuklającej jedność działania i komunikowania się oraz w perspektywie konstruktywistycznej wskazującej na fakt, że wiedza jest budowania przez osoby uczące się, które współpracują ze sobą, a nie zaś tylko przekazywana i zapamiętywana. Na koniec sformułujemy wnioski i omówimy napotkane w badaniu trudności. 


\section{Refleksja w nauczaniu/uczeniu się języka}

Refleksja (lub też myślenie refleksyjne) pojawia się wtedy, kiedy osoba zauważa lub odczuwa pewną trudność, niepewność lub wątpliwość, która staje się na tyle ważna dla tej osoby, że odczuwa ona potrzebę jej rozwiązania lub wyjaśnienia (zob. Dewey 1988: 36). Problem staje się wtedy celem myślenia i wypełnia myślenie swoją treścią. Refleksyjny uczeń, który napotyka na trudność, czy wątpliwość językową, zaczyna zastanawiać się. Niepewność i ciekawość zaczynają stanowić jedność. Uczeń przeszukuje więc pamięć, łączy nowe informacje z posiadaną już wiedzą, buduje przesłanki, będące podstawą do formułowania wniosków. Nierzadko także zaczyna poszukiwać informacji w różnych źródłach. Problemy dotyczą oczywiście nie tylko języka, ale i komunikacji w tym języku, relacji interpersonalnych, budowania kompetencji komunikacyjnych i ogólnych oraz wielu innych jeszcze kwestii.

Nasze doświadczenie nauczyciela wskazuje, że miejscem które sprzyja szczególnie pojawianiu się różnorodnych problemów, mogących stanowić podstawę do refleksji i w efekcie do budowania wniosków jest klasa językowa, w której uczenie się oparte jest na wspólnym wykonywaniu zdań. W klasie tej konfrontowane są różne opinie i potrzeby, ujawniają się różne osobowości i kompetencje. Wspólne zadanie stanowiące wspólny cel sprzyja więc współpracy (a więc i pokonywaniu różnic), ale też i powstaniu konfliktu kognitywnego (zob. szerzej: Piegzik, 2011) oraz ujawniania odmiennych zachowań komunikacyjnych i zachowań związanych z uczeniem się, mogących stanowić ważne doświadczenie dla każdego uczącego się w tej grupie. Doświadczenie to oparte na interakcjach uczącego się z innymi uczącymi i nauczającym stawiamy w centrum kształcenia językowego, wskazując na jego wartość poznawczą, afektywną i społeczną (por. także ESOKJ 2001). Przypuszczamy, że właśnie w takiej klasie językowej możliwe jest nie tyle nabywanie nowych informacji, powiększających wiedzę ucznia (oparte głównie na rozumieniu i zapamiętywaniu), ale samodzielne jej konstruowanie związane $z$ analizą i krytycznym myśleniem. Mamy tutaj na myśli samodzielne operacje myślowe związane z interpretacją nowych danych, u podstaw których leżą wspólne interakcje werbalne. W ten sposób wiedza nie jest kompilacją danych, przekazywaną od jednej osoby do drugiej, ale stanowi spójny i logiczny konstrukt wytwarzany samodzielnie w toku refleksji osoby uczącej się.

W opisywanym przez nas poniżej badaniu nowe doświadczenie uczenia się języka poprzez wykonywanie zadań, jak również prowadzenie dzienniczków stało się dla wielu osób inspiracją do podejmowania szeregu refleksji, z których wynikła nowa wiedza oraz, jak się okazało w toku badania, tak- 
Od refleksji do konstruowania wiedzy i wspólnoty komunikacyjnej: wyniki...

że konieczność wnikliwego przemyślenia i praktycznego zbudowania wspólnoty komunikacyjnej, w której odbywał się proces uczenia się języka.

\section{Badanie $\mathbf{w}$ działaniu jako metoda badania nad refleksją}

Głównym celem językowym przeprowadzonego przez nas badania było kształtowanie umiejętności uczestniczenia $w$ działaniach negocjacyjnych, jednym zaś z celów pozajęzykowych - rozwijanie refleksji. Ze względu na specyfikę wyróżnionych celów, odwołaliśmy się do metodologii jakościowej. Obie wskazane umiejętności stanowią bowiem złożone procesy, na przebieg których wpływ mają czynniki wewnętrzne (myśli, emocje) oraz czynniki zewnętrzne (np. współpraca z innymi), które nie podlegają opisowi ilościowemu. W ramach metodologii jakościowej wybraliśmy badanie w działaniu, które wiąże się z podwójną rolą badacza-nauczyciela znajdującego się, na wzór podejścia etnograficznego, w badanym przez siebie środowisku (Wilczyńska i Michońska-Stadnik 2010: 153), w którym możliwe jest monitorowanie 'od środka' i stosunkowo łatwy oraz stały dostęp do danych. Innym ważnym powodem wyboru metody badawczej był fakt, iż metoda ta pozwala na osadzenie wybranego przedmiotu badań w naturalnym, tj. znanym uczniom kontekście dydaktycznym pozbawionym elementów nowych i tym samym sztucznych, które mogłyby wpłynąć na zmianę zachowania. Nie bez znaczenia był również fakt, iż u podstaw wybranego badania znajduje się dialog ucznia z nauczycielem oraz uczniów ze sobą. Rozmowa, podczas której ma miejsce pogłębianie aspektów wspólnego i indywidualnego uczenia się/nabywania kompetencji rodzi zdolność do refleksji, z której wynika świadomość ucznia.

W zdefiniowanej kluczowej dla badania kategorii 'umiejętność uczestniczenia w działaniach negocjacyjnych' (por. Piegzik 2011:110-113) wyróżniliśmy umiejętności językowe (np. umiejętność współkonstrowania dyskursu w języku obcym) oraz umiejętności ogólne (np. umiejętność współpracy). Za kluczową umiejętność ogólną uznaliśmy umiejętność bycia osobą refleksyjną oraz stawania się osobą świadomą siebie i własnych zachowań. Wybraliśmy tę umiejętność jako nadrzędną, ponieważ z refleksji rodzi się świadoma wiedza, która może być podstawą do podejmowania nowych zachowań, korekty starych i w efekcie do rozwoju. Refleksja i wiedza zbudowana w jej następstwie pozwala uczącemu się na samokontrolę, samocenę, zdanie sobie sprawy ze swoich mocnych i słabych stron, w końcu także na samodzielne podejmowanie decyzji i branie za nie odpowiedzialności. W związku z powyższym badanie miało także na celu ukazanie, że lekcja języka obcego w grupie jest okazją do kształcenia kompetencji językowych oraz kompeten- 
cji ogólnych, mogących mieć wpływ na cały (a nie tylko językowy) proces kształcenia oraz na rozwój umiejętności ważnych w przyszłym życiu zawodowym i osobistym ucznia. Jedno z pytań badawczych brzmiało:

PS1: W jakim zakresie udział w pracy projektowej rozwinie u uczniów świadomość własnego uczenia się, tj. świadomość własnej motywacji do uczenia się języka w interakcji, stosowanych strategii, świadomość własnych zachowań komunikacyjnych oraz przebiegu uczenia się języka?

Jako metodę nauczania/uczenia się wybrano pracę projektową, gdyż łączy ona komunikację z działaniem społecznym, nie rozdzielając procesu uczenia się i komunikowania. Nauka języka obcego nie polega już tylko na samym komunikowaniu się, gdzie język jest środkiem i celem, lecz na realizacji większego zadania, które wymaga od uczniów poszukiwania adekwatnych informacji, użycia różnych strategii, licznych przemyśleń odnoszących się do procedury wspólnych działań, wybranych materiałów, także refleksji nad sobą jako negocjatorem i partnerem we wspólnym uczeniu się i komunikowaniu.

\subsection{Uczestnicy badania}

W badaniu udział wzięła grupa szesnastu uczących się, dla których język francuski stanowił drugi język obcy. W momencie rozpoczęcia badania uczniowie reprezentowali poziom A2, który pozwalał im na samodzielne budowanie prostych wypowiedzi na zrealizowane wcześniej tematy oraz proste interakcje w oparciu o poznane słownictwo oraz gramatykę. Uczestnicy badania znali metodę pracy projektowej i mieli w tym zakresie spore doświadczenie. Nigdy jednak nie wykonywali pracy projektowej w grupie uczeniowej w żadnym języku obcym. Świadomość niskiego poziomu zaawansowania językowego budziła początkowo u uczestników badania obawy. Ustąpiły one jednak, kiedy uczniowie poznali różne strategie komunikacyjne oraz kiedy ustalono, że wszelkie 'nieudane' próby komunikacyjne nie będą oceniane. Wszyscy wyrazili zgodę na nową metodę pracy, tj. wspólne wykonywanie zadań, na nagrywanie kamerą wideo etapu realizacyjnego, podczas którego dochodzi do największej ilości negocjacji treści i procedury działania oraz indywidualne prowadzenie dzienniczków uczestnika badania. Tematy zadań i prac projektowych związane były ściśle z obowiązującymi treściami kształcenia zawartymi w obowiązującej Podstawie Programowej, która na drugi język obcy wyznaczała dwie godziny w tygodniu. 
Od refleksji do konstruowania wiedzy i wspólnoty komunikacyjnej: wyniki...

\subsection{Narzędzia badawcze}

W badaniu wykorzystano kilka narzędzi badawczych. Pierwszym była kamera wideo, na którą nagrywano fazę scalania uprzednio wynegocjowanych i przygotowanych zadań. Nagrania były każdorazowo wspólnie z nauczycielem oglądane i komentowane. Podczas dyskusji wyłaniano zachowania grupy, które przyczyniły się do sprawnego wykonania zadania oraz sprawnej komunikacji, jak również zachowania blokujące lub hamujące porozumienie i sprawną realizację projektu. Chodziło o rozbudzenie refleksji odnoszącej się do zachowań własnych oraz zachowań innych osób, do siebie jako osoby, jako ucznia oraz partnera komunikacyjnego.

Innym narzędziem badawczym był dzienniczek uczestnika badania, który prowadził każdy biorący w badaniu uczeń. Podczas opisywanego badania zdecydowano się na interaktywną formę prowadzenia dzienniczka, która zdaniem uczestników badania bardziej motywowała ich do systematycznego redagowania przemyśleń i obserwacji. Terminy oddawania dzienniczków nauczycielowi nie zostały odgórnie narzucone, choć uczący się wiedzieli, że częste redagowanie sprzyja systematycznemu rozwojowi refleksji i świadomości.

Rozwijaniu refleksji służyła także karta samooceny. Był to dokument opracowany przez uczestników badania i nauczyciela. Karta zawierała trzy grupy pytań odpowiadające trzem fazom pracy projektowej. Odpowiedzi były zamknięte i odnosiły się do stopnia opanowania danej umiejętności przez ucznia (np. potrafię wyrażać zgodę/niezgodę; potrafię harmonijnie i często przejmować głos w dyskusji). Samoocena uczącego się nie miała wpływu na ocenę nauczyciela. Kartę samooceny wypełniał każdy uczeń po zakończeniu każdej pracy projektowej. W praktyce, czyli podczas ośmiu miesięcy trwania badania, zrealizowano trzy prace projektowe i każdy uczeń wypełnił trzy karty samooceny.

Badanie poprzedzono i zakończono dyskusją w języku polskim. Celem pierwszej było rozbudzenie świadomości celów wspólnej nauki. Celem drugiej - podsumowanie pracy oraz refleksja nad osiągnięciami i możliwościami ich wykorzystania w przyszłości.

\section{Wyniki badania}

Z przeprowadzonego badania wynika, że klasa językowa, w której naucza się drugiego języka obcego, na który przypada znacznie mniejsza liczba godzin w całym cyku kształcenia średniego niż na język pierwszy (w znakomitej większości język 
angielski), może być miejscem jednoczesnego kształcenia kompetencji komunikacyjnej oraz kompetencji ogólnych, w tym umiejętności bycia refleksyjnym.

\subsection{Konstruowanie wspólnoty komunikacyjnej}

Badanie ujawniło, że zarządzanie projektem przez uczących się nierozerwalnie łączy się z przejmowaniem odpowiedzialności za komunikację. Nauczający nie jest już osobą zarządzającą konstruowanym w klasie dyskursem, która weryfikuje poprawność uczniowskich wypowiedzi, ale raczej obserwatorem, czasem doradcą. Rolę nauczyciela jako szefa komunikacji (fr. chef de parole), przejmują na zmianę poszczególni uczący się, którzy współpracując z pozostałymi osobami w grupie, dążą do konstruowania wspólnoty komunikacyjnej, w której wszyscy mają prawo do swobodnego wyrażania własnych opinii. W ten sposób klasa nie jest daną, gotową, zastaną przez uczących się przestrzenią, którą zarządza nauczyciel i która zdeterminowana jest przez odgórnie narzucony program. Klasa staje się przestrzenią, która powstaje w wyniku działań komunikacyjnych jej uczestników. Przypomina ona rzeczywistość społeczno-kulturową pojmowaną w duchu konstruktywistycznym, gdzie ludzkie zbiorowości konstruują swoje wyobrażenia i/lub pojęcia świata i za pomocą których możliwe jest tworzenie poszczególnych elementów tego świata (zob. szerzej Wendland 2011: 13). Budowanie takiej wspólnoty łączy się w klasie językowej (podobnie jak w każdym kontekście życia społecznego) z posiadaniem zbieżnych celów oraz posługiwaniem się (nawet w ograniczonym zakresie) tym samym językiem. W naszym przypadku istotnym elementem jest również fakt świadomego dzielenia się swoją wiedzą i doświadczeniem $z$ innymi, w taki sposób, aby budowana rzeczywistość stanowiła przestrzeń, w której każdy może swobodnie rozwijać własne kompetencje. Opisywana w pracy wspólnota to zatem „,mikro społeczność”, gdzie przebiega zorganizowane i zaplanowane kształcenie językowe, uwypuklające praktyczne działanie implikujące w sposób naturalny interakcje werbalne. W prezentowanym badaniu nowe doświadczenie samodzielnego kierowania komunikacją i budowania wspólnoty zainspirowało do wyrażania szeregu opinii, nasunęło szereg wątpliwości i trudności. Poniżej cytujemy fragmenty wypowiedzi związane z refleksjami na ten temat różnych uczestników, którzy pełnili różne role we wspólnej pracy nad powierzonymi zadaniami ${ }^{1}$.

\footnotetext{
${ }^{1}$ Cytowane w pracy przykłady zaczerpnięto z dzienniczków uczestnika badania przeprowadzonego badania w działaniu oraz z transkrypcji korpusu wideo zawartej w niepublikowanej rozprawie doktorskiej W. Piegzik (2011). Interakcje negocjacyjne w pracy projektowej licealistów (na przykładzie języka francuskiego jako obcego). Poznań: UAM.
} 
KR: Mi, jako animatorowi, było trudno zachęcić kilka osób do rozmowy. Nie wiem, czy wynikało to z ich niechęci, strachu przed dyskusją, czy to ja wybierałam złe momenty. Poza tym wydaje mi się, że jak na nasze umiejętności do dyskusji, dość dobrze spełniłam swoją rolę. W następnej negocjacji spróbuję zachęcić do rozmowy wszystkich, a silnym osobowościom dać dodatkowe pole do popisu.

Cytowana wypowiedź jest przykładem refleksji nad sposobami pokonania napotkanych trudności komunikacyjnych. Widoczne są w niej próby formułowania przesłanek, które odnoszą się zarówno do uczestników grupy, jak i samej uczennicy. Uczestniczka badania poszukuje przyczyn trudności komunikacyjnych tak na zewnątrz, jak i wewnątrz samej siebie. Świadczyć to może - zgodnie z założeniami teorii atrybucji ${ }^{2}$ - o jej myśleniu przyczynowo-skutkowym, które dąży do poznania obiektywnych racji oraz pokonania jednostronnych i schematycznych interpretacji. Niezależnie od przyczyny napotkanych trudności komunikacyjnych, animatorka znajduje rozwiązanie, które wiąże się z odmiennym podejściem do grupy nieaktywnej oraz które otwiera nowe możliwości dla części grupy aktywnej. Cytowana wypowiedź ma charakter osobisty, o czy świadczy narracja pierwszoosobowa i formuła pytań stawianych samej sobie.

Wnioski wynikające z odbytych refleksji są przez uczestniczkę badania wdrażane w praktykę dyskursywną. Służą one praktycznemu budowaniu wspólnoty komunikacyjnej, w której jest miejsce na rozwijanie kompetencji językowych i ogólnych. Oto przykład ${ }^{3}$ (Tabela 1):

\begin{tabular}{|c|c|}
\hline Transkrypcja interakcji w języku francuskim & Tłumaczenie interakcji na język polski \\
\hline $\begin{array}{l}\text { KR. quelle idée est meilleure' la gare } \\
\text { ou(1.0)*l'église*' }\end{array}$ & $\begin{array}{l}\text { KR. który pomysł jest lepszy' dworzec czy } \\
\text { (1.0)*kościół*' }\end{array}$ \\
\hline BG. heu la gare & BG. yy dworzec \\
\hline AG. la gare' & AG. dworzec' \\
\hline KR. oui (.) parce que' & KR. tak (.) ponieważ' \\
\hline $\begin{array}{l}\text { BG. parce que la gare est (.) est important(.) } \\
\text { et c'est heu }\end{array}$ & $\begin{array}{l}\text { BG. ponieważ dworzec jest (.) jest ważny(.) } \\
\quad i \text { to jest } y\end{array}$ \\
\hline AG. pour visiter $=$ & AG. do zwiedzania $=$ \\
\hline$B G .=$ pour visiter & $B G .=$ do zwiedzania \\
\hline
\end{tabular}

\footnotetext{
${ }^{2} \mathrm{~W}$ artykule odnosimy się do znanej powszechnie w naukach humanistycznych oraz społecznych teorii atrybucji, za ojca której zwykło się uważać Fritza Heidera. Teoria, najogólniej mówiąc, wyjaśnia w jaki sposób człowiek interpretuje zachowania własne oraz cudze.

${ }^{3}$ Ważniejsze symbole transkrypcyjne: (.) mikropauza, (2.0) pauza w sekundach, : przedłużenie dźwięku (liczba kropek zależna od skali przedłużenia), ' wznosząca się linia intonacyjna, = rozpoczęcie kolejnej wypowiedzi bez pauzy, snie nie nieı wypowiedź szybsza od pozostałych, tak wypowiedź w języku polskim, (pour que) niepewne odczytanie słowa, [początek realizowanych jednocześnie wypowiedzi, *l'église* wypowiedź cichsza niż reszta wypowiedzi w jej otoczeniu, LES TITRES wypowiedź głośniejsza niż reszta w jej otoczeniu.
} 


\begin{tabular}{|c|c|}
\hline $\begin{array}{l}\text { AK. (xxx) } \\
\text { KR. oui(.) et c'est c'est plus moderne que } \\
\quad \text { que l'église et c'est(.)différente chose(.) } \\
\quad \text { oui' et c'est bon pour présenter } \\
\quad \text { différentes choses(.)oui' } \\
\text { BG. oui } \\
\text { AG. oui }\end{array}$ & $\begin{array}{l}\text { AK. (xxx) } \\
\text { KR. tak(.) i jest jest nowocześniejszy niż niż } \\
\quad \text { kościół i to jest (.) inna rzecz(.) tak' i do- } \\
\quad \text { brze jest przedstawić różne rzeczy (.)tak' } \\
\text { BG. tak } \\
\text { AG. tak }\end{array}$ \\
\hline
\end{tabular}

Tabela 1: Interakcje uczestników badania, podczas których konstruowana jest wspólnota komunikacyjna.

Jak wynika z cytowanego fragmentu, animatorka zachęca wszystkich uczestników do wypowiadania się głównie poprzez częste i krótkie pytania. Pytania dotyczą opinii, zgody na podjętą decyzję lub też uzasadnienia opinii. Uzasadnianie związane z próbą budowania argumentacji widoczne jest w krótkim parce que' (ponieważ'), które wymusza na rozmówcy prezentację argumentu oraz które 'w zgrabny sposób’ przedłuża lakoniczną wypowiedź. KR zgodnie z dokonanymi ustaleniami w dzienniczku nie narzuca rozmówcom swoich rozwiązań. Brak charakteru decyzyjnego widoczny jest w systematycznym zwracaniu się go grupy i chęci poznania jej opinii. Taki styl pracy sprzyja, jak można zauważyć w cytowanym fragmencie, współpracy uczestników, którzy pomimo niskiego poziomu zaawansowania językowego, dokonują, posługując się wyłącznie językiem francuskim, serii negocjacji treści, z których wynikają ustalenia do wspólnego projektu.

\subsection{Konstruowanie wiedzy praktycznej}

Zbudowana wspólnota komunikacyjna staje się w opisywanym badaniu miejscem obserwacji i praktycznych działań jej współtwórców. Obfituje ona w różnorodne dane inspirujące liczne refleksje. $Z$ refleksji tych wynika świadoma wiedza uczących się, która systematycznie jest budowana i prezentowana w dzienniczkach uczestników badania. Wątkami najczęściej podejmowanymi są: strategie uczenia się języka, zasady skutecznej komunikacji, różnice pomiędzy komunikacją w języku rodzimym a obcym, rola języka ciała i komunikacji niewerbalnej oraz wiele innych. Oto przykład wypowiedzi uczestniczki badania, która w wyniku obserwacji grupy formułuje zasady komunikacji w grupie, a następnie stosuje je w praktyce.

BG: W komunikacji ważne jest uzyskanie jej efektu (ale takiego, który zadowala każdego z rozmówców - aby doszli do porozumienia). Rozmówcy powinni uważnie się słuchać, być interaktywni, z ciekawością się dopytywać drugiej osoby, patrzeć sobie w oczy (żeby rozmówca czuł, że się go słucha), 
mówić przyjaznym tonem głosu, gestykulować (wtedy wypowiedź jest bardziej żywa), reagować na komunikaty (...).

Sformułowana wypowiedź stanowi próbę podsumowania tego, czym jest komunikacja $\mathrm{w}$ grupie $\mathrm{i}$ jakie cechy powinna ona posiadać. $Z$ wypowiedzi wynika, że BG kładzie nacisk na skuteczność komunikacji, przez którą rozumie uzyskanie satysfakcjonującego dla wszystkich porozumienia. Jest prawdopodobne, że wniosek ten wynika z szeregu negocjacji odbytych w klasie, których celem był właśnie konsensus, a nie tylko wymiana informacji bez próby zakreślenia wspólnych wniosków. Znamienny być może również fakt, iż uczestniczka badania wskazuje nie tylko na efekt końcowy komunikacji, ale podkreśla wagę całego procesu dochodzenia do niego. Wśród działań sprzyjających skutecznej komunikacji wylicza ona zarówno te, które łączą się z interakcjami stricte werbalnymi (np. interaktywność), jak i te, które dotyczą działań para i niewerbalnych (ton głosu, kontakt wzrokowy, gestykulacja). Jest to zatem dość wszechstronne spojrzenie na komunikację ujawniające jej istotę (porozumienie) oraz elementy konstytutywne. Zachowania komunikacyjne BG i grupy, w której realizuje ona projekt ujawniają, że sformułowana przez nią wiedza o charakterze praktycznym znajduje swoje odbicie w konkretnych zachowaniach dyskursywnych (Tabela 2).

\begin{tabular}{|c|c|c|c|}
\hline \multicolumn{2}{|c|}{ Transkrypcja interakcji w języku francuskim } & \multicolumn{2}{|c|}{ Tłumaczenie interakcji na język polski } \\
\hline$K P$. & $\begin{array}{l}\text { okey'(1.0)nous(.)nous avons le projet'(1.0) } \\
\text { c'est fini' }\end{array}$ & $K P$. & 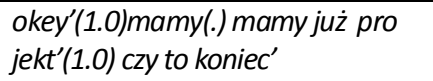 \\
\hline Grol & non & Grupa. & nie \\
\hline$A K$. & non & $A K$. & nie \\
\hline$J U$. & le titre (pokazuje palcem materiały) & $J U$. & tytut (pokazuje palcem materiały) \\
\hline$A K$. & kuluje heh) & $A K$. & [TYTUtYROZDZIAtÓW (gestykulujeheh) \\
\hline$B G$. & [les tit & $B G$. & [tytuły rozdziałów \\
\hline$J U$. & $\begin{array}{l}\text { le titre (pokazuje miejsce na kartce, w } \\
\text { którym trzeba wpisać tytuł) }\end{array}$ & $J U$. & $\begin{array}{l}\text { tytut (pokazuje miejsce na kartce, } \\
\text { w którym trzeba wpisać tytut) }\end{array}$ \\
\hline$K P$. & okey(.) *nie wiedziałam* (sięga po materiały) & $K P$. & okey(.) *nie wiedziałam* (sięga po \\
\hline$B G$. & j'ai la proposition & & materiały) \\
\hline$K P$. & oui' & $B G$. & Mam propozycję \\
\hline$B G$. & pour Edith Piaf (...) la voix de la & $K P$. & $t_{a k}$ \\
\hline & $\begin{array}{l}\text { France(.) (gestykuluje rękq i uśmiecha się) } \\
\text { oui(.) okey(.) może tu' }\end{array}$ & $\begin{array}{l}B G . \\
K P .\end{array}$ & $\begin{array}{l}\text { dla Edith Piaf (...) głos Francji(.) } \\
\text { (gestykuluje rękq i uśmiecha się) } \\
\text { tak(.) okey(.) może tu' }\end{array}$ \\
\hline
\end{tabular}

Tabela 2. Interakcje uczestników badania, podczas których wdrażana jest w praktykę skonstruowana wiedza na temat komunikacji.

Powyższy fragment ukazuje, iż grupa, w której uczestniczka badania (BG) pracuje nad projektem stanowi zespół osób współpracujących i aktywnie słuchają- 
cych się. Próba zakończenia pracy przez animatorkę kończy się protestem grupy, która kontroluje realizację wszystkich przewidzianych zadań, w tym sformułowania tytułów do poszczególnych rozdziałów folderu o sławnych Francuzach. Głośniejsze i równoczesne wypowiedzi świadczą o ożywieniu komunikacji. W takiej też atmosferze uczestniczka BG wysuwa swoją propozycję, jej gestykulacja i uśmiech mogą świadczyć o naturalności zachowania. Fragment ujawnia, że sformułowane $w$ dzienniczku wnioski nie są tylko deklaracjami, lecz kryją się za nimi konkretne zmiany zachowania, świadczące o dokonującym się rozwoju.

\subsection{Konstruowanie wiedzy teoretycznej}

Wśród wypowiedzi uczestników badania da się również wskazać takie, których autorzy dążą do sformułowań mających charakter ogólny i uniwersalny. Uczniowie ci odnoszą się do posiadanej już wiedzy z danej dziedziny, korzystają z nowego doświadczenia uczenia się $\mathrm{w}$ grupie oraz próbują skonstruować własne wnioski. Sformułowania tego typu nazwaliśmy 'konstruowaniem wiedzy teoretycznej', ponieważ odnieść je można do różnych teorii próbujących wyjaśnić proces uczenia się, zjawisko samoświadomości, także dyscyplin zajmujących się wymienionymi fenomenami np. do nauk kognitywnych. Wypowiedzi te mają także charakter wyjaśniający, cechujący opisy teoretyczne. A oto przykład:

PD: To że mamy świadomość swojego samokształcenia, a więc to czy wiemy, że jesteśmy np. wzrokowcem, słuchowcem, itd. itd., to nic innego jak świadomość swojego umysłu, a zatem i mózgu.

Uczestnik badania w swoich przemyśleniach utożsamia samoświadomość kształcenia ze świadomością posiadanego typu percepcyjnego. Takie odkrycie pozwala mu na odnalezienie paralelności pomiędzy wskazanymi zjawiskami intelektualnymi. Powyższy przykład świadczyć zapewne może o umiejętności transferu posiadanej już wiedzy biologicznej do obszaru uczenia się języka obcego i zdobywania kompetencji uczenia się w grupie. Samodzielnie wyprowadzone wnioski są dowodem odbytej refleksji, z której wynika świadomość siebie oraz posiadanej wiedzy ${ }^{4}$.

${ }^{4} \mathrm{O}$ ile refleksję postrzegamy jako proces mentalny związany z przetwarzaniem informacji, któremu towarzyszy logiczne łączenie poszczególnych elementów/ogniw tego procesu, o tyle za jej skutek/efekt uważamy świadomość (wiem już, że wiem oraz wiem, co wiem). Z tego też względu niniejszą pracę należy uznać jako komplementarną do innej poświęconej zjawisku świadomości uczenia się języka obcego napisaną przez piszącą te słowa (Por. Piegzik: 2013). 


\section{Wnioski}

Zrealizowane badanie w działaniu ujawniło, że rozwijanie refleksji u uczących się języka oparte na prowadzeniu dzienniczków i dyskusjach towarzyszących oglądaniu nagrań wideofonicznych pociąga za sobą modyfikacje w zachowaniach komunikacyjnych i zachowaniach związanych z procesem uczenia się. $Z$ badania wynika, że istotną przyczyną dokonanych zmian była zbudowana wspólnie mikro społeczność umożliwiająca jej uczestnikom i konstruktorom możliwość świadomej obserwacji i krytycznej analizy wielu różnych stylów uczenia się i komunikowania, różnych poglądów i prezentowanych faktów. Zbudowana w klasie wspólnota komunikacyjna stanowiła przestrzeń nowych doświadczeń, miejsce poddania w wątpliwość dotychczasowych nawyków mentalnych (ang. mental habits), preferencji, ideologii, wartości, także zachowań komunikacyjnych w języku obcym (por. także Mezirow 2001; Duchesne 2010). Dla wielu uczestników badania stare nawyki (praca tylko dla siebie, realizacja tylko własnych celów, zapamiętywanie treści, zastanie klasy jako przestrzeni już zorganizowanej i kierowanej przez nauczyciela) okazały się nieskuteczne w nowej sytuacji uczenia się. Pełnienie zaś nowych ról w klasie wymusiło aktywność i myślenie w kategoriach wspólnego celu.

Z badania wynika, że o ile refleksja uczących się pociągnęła za sobą rozwój ich kompetencji ogólnych (zdolność i chęć do współpracy, poszerzanie wiedzy ogólnej, samoświadomość), o tyle postęp w zakresie rozwijania kompetencji językowej oraz dyskursywnej, przez którą rozumiemy umiejętność współkonstruowania poprawnego językowo i logicznie dyskursu, nie był końca równoległy. O ile pierwsze znaczące zmiany świadczące o rozwoju refleksji i kompetencji ogólnych są zauważalne już właściwie na przełomie drugiego i trzeciego miesiąca badań, o tyle przyrost umiejętności językowych następował wolniej i do końca ostatniego miesiąca badań uczący się mieli problemy z budowaniem zdań złożonych lub też dłuższych kilkuzdaniowych wypowiedzi. W wypowiedziach uczestników badania da się zauważyć przewagę prostych struktur leksykalno-gramatycznych oraz słownictwo o dużym stopniu pospolitości. Błędy są częste, głównie gramatyczne, nie zakłócają one jednak komunikacji. Uczący się często posługują się wyrażeniami eliptycznymi lub urywają rozpoczęte zdanie. Ich wymowa jest jednak z reguły poprawna, respektują oni np. zjawisko elizji czy łączenia międzywyrazowego. Należy również zaznaczyć, że pomimo wspomnianych trudności językowych uczestnicy badania osiągnęli sporą płynność językową, która pozwoliła im na sprawne budowanie wspólnego dyskursu. Myślimy tu o częstym przejmowaniu głosu przez różnych uczestników, odnoszeniu się do wypowiedzi poprzedników oraz składaniu propozycji do wspólnego projektu. Do innych 
napotkanych trudności zaliczyć należy brak możliwości redagowania dzienniczka w języku francuskim. Poziom A2 uniemożliwił swobodne wypowiadanie się na tematy dotyczące własnego uczenia się języka w grupie. Z tego względu w opisywanym w pracy badaniu nie dochodziło do transferu umiejętności: od umiejętności redagowania do wypowiadania się. Przypuszczamy, że o ile umiejętności językowe uczestników badania byłby wyższe, tj. pozwalałyby na swobodne wypowiadanie się w języku obcym w dzienniczkach, wyższy byłby także przyrost kompetencji językowych. Należy również zaznaczyć, iż niektórzy uczestnicy badania mieli także problem z systematycznością prowadzenia dzienniczków, co wynikało głównie z faktu, iż nie zdecydowano się na wyznaczanie konkretnych dat oddawania dzienniczka, uznając, iż refleksja rodzi się w określonych momentach, nie zaś 'na zawołanie'. Z dokonanej analizy wynika jednak, iż dane ilościowe (częstotliwość oddawania dzienniczka) są wprost proporcjonalne do pogłębionych refleksji i konstruowanych wniosków (dane jakościowe) ${ }^{5}$. Oznacza to, że im częściej dokonywane były zapisy, tym refleksja uczących się i ich świadoma wiedza były większe. Myślimy tu o wnioskach wynikających z dokonanych analiz, sformułowaniach odnoszących się doskonalenia własnej pracy i pracy w grupie, mniej zaś o relacjonowaniu faktów i subiektywnych ocenach.

W opisywanym badaniu narzędziem najbardziej stymulującym refleksję był dzienniczek. Dzienniczki zresztą, podobnie jak nagrania wideofoniczne dostarczyły także najwięcej danych pozwalających na analizę zagadnienia rozwijania refleksji u uczących się. Niski stopień stymulacji okazała się mieć natomiast karta samooceny. Wydaje się zatem, iż formuła gotowych odpowiedzi posiada w konfrontacji z formą otwartą dzienniczka dużą mniejszą moc stymulacji refleksji. Niski stopień stymulacji karty może jednak dziwić, ponieważ był to dokument opracowany przy współpracy wszystkich uczniów-uczestników badania oraz nauczyciela.

Reasumując, należy uznać, że grupowe wykonywanie zadań ukierunkowane na świadomą obserwację grupy i rozwój refleksji przyczyniło się do pogłębienia umiejętności ogólnych, językowych i dyskursywnych, zaś zbudowana wiedza praktyczna i teoretyczna stanowią bogaty dorobek każdego uczestnika opisanego tu badania.

\section{BIBLIOGRAFIA}

Cassirer, E. 1998. Esej o człowieku. Wstęp do filozofii kultury. przeł. A. Staniewska. Warszawa: Czytelnik.

${ }^{5}$ Por. szerzej Piegzik (2011:173-177). 
Council of Europe. 2003. Europejski System Opisu Kształcenia Językowego: uczenie się, nauczanie, ocenianie. Warszawa: Wydawnictwa CODN.

Dewey, J. 1988. Jak myślimy ? przeł. Z. Bastgenowa. Warszawa: PWN.

Duchesne, C. 2010. „,L'apprentissage par transformation en contexte de formation professionnelle". Education et francophonie vol. XXXVIII (1): 33-50. http://www.acelf.ca/c/revue/pdf/EF-38-1-033_DUCHESNE.pdf DW 19.03.2013

Mezirow, J. 2001. Penser son expérience. Développer I'autoformation. Lyon: Cronique Sociale.

Piegzik, W. 2011. „Interakcje negocjacyjne w pracy projektowej licealistów (na przykładzie języka francuskiego jako obcego)". Niepublikowana rozprawa doktorska. Poznań: UAM.

Piegzik, W. 2013. „Rola świadomości uczenia się a rozwój językowych kompetencji komunikacyjnych : podejście zadaniowe" (w:) Dydaktyka języków obcych a kompetencje ogólne (red. J. Stańczyk i E. Nowikiewicz), Bydgoszcz: NKJO: 85-97.

Wendland, M. 2011. Konstruktywizm komunikacyjny. Poznań: Wydawnictwo Naukowe IF UAM.

Wilczyńska, W i Michońska-Stadnik, A. 2010. Metodologia badań w glottodydaktyce. Wprowadzenie. Kraków: Avalon. 